\title{
Edward Said's Conception of the Intellectual Resistance
}

\author{
Yasif Ahmad Faysal ${ }^{1}$, Md. Sadequr Rahman ${ }^{2 *}$ \\ ${ }^{1}$ Lecturer, Department of English, University of Barisal, Barisal, Bangladesh \\ ${ }^{2}$ Lecturer, Department of Sociology, University of Barisal, Barisal, Bangladesh \\ *Corresponding author: Email: sadeksociology2000@yahoo.com
}

\begin{abstract}
This paper attempts to focus on the Saidian intellectual who plays an exemplary role in resisting the ideological misrepresentation that a dominant culture performs over the weak one, which eventually leads to imperialism and colonialism. This resistance is a highly intellectual one and bound with some critical practices on the part of the intellectual himself. Essentially non-coercive in nature, the resistance entails a mode of criticism from him, which is secular in being opposed to dogmatic obsession, amateurist in being free from the traps of professionalism, exilic in having pluralistic viewpoints. The task of resistance also requires an intellectual as critic to consider a cultural artifact like a novel as product of worldly circumstances, which is deeply inflected with the ideological position of the author himself. This, correspondingly, requires a critic to switch from filiative criticism, that texts are traditionally homogenized, to the affiliative one, that they bear the determining imprints of hegemonic influences of cultures, often imperialistic ones. Benefitting from all these insights, an intellectual can participate in a cultural and specifically literary mode of resistance by producing counter- discourse that he terms voyage-in. Eventually, these practices generates a moral courage for a critic and enables him to speak truth to power in all its forms and manifestation.
\end{abstract}

Key Words: Non-coercive resistance, secular criticism, amateurism, exilic consciousness, worldliness, voyage-in

\section{Introduction}

The role of Edward Said in advanced and critical studies on post colonialism is overwhelmingly influential and his critical formulation of the concept of intellectual resistance carries weight and significance far greater than many practising theorists in the post-colonial studies. The publication of his seminal book Orientalism (1983) had a groundbreaking impact on this field and inspired researchers around the globe to take bold and innovative ways of reappraising colonial discourses in a manner so far unknown to them. The range and intensity of the book touches issues both intellectual and common place and constitute intimate facts of life for people living in postcolonial world. In this book and others that followed in a career that was marked by high academic accomplishment, prolific critical thoughts, global attention, political displacements, controversy, and a battle lost to cancer, Said unfailingly rose to the task of championing the truth and to the most challenging task of all "speaking truth to power" (Said, 1994: 75). It is his consistent investigation of the ways how the production of knowledge even in its most disinterested discursive manner pioneers the process of colonization that has made his name and his works the most important reference point in postcolonial studies all around the world. However, there has been a critical debate whether Said, despite his groundbreaking works like Orientalism, has successfully and systematically envisioned ways to tackle discursive and epistemological totalisation that the west has historically performed the rest of the world or he has succumbed to the very evil that he set out to resist, namely the misrepresentation of the east by the west. It has been argued that Said in holding Orientalism responsible for imperialism has himself participated in an over-generalized critique of it and been guilty of Occidentalism- a charge brought by his critics. In this essay, we attempt to prove that neither of these charges does apply to Said and that Said does, indeed, offer us a very conscious program of resistance, cultural in mode and materialized only through the exemplary role of intellectual facing the vicissitudes of a world going increasingly under the sway of cultural hegemony and aggression.

\section{Literature Review}

Said postulates a non-coercive model of resistance. Aware of Nietzchean dictum 'will to power' and that the truth of language is nothing but "illusions about 
which one has forgotten that this is what they are", Said effectively combines Nietzchean insight with the Foucaultian one of discursive formation of power and with the Gramscian view of how culture imposes its authority on all avenues of life through hegemonic operation, Said's vision of resistance is an unique one, in which he emphatically veers away from the oppositional or conflictual dimension of resistance but looks upon resistance as a task to be actively performed from within culture by effectively creating counter-discourse by intellectual. However, Said's view that the west has always worked to produce discourses for "dominating, restructuring, and having authority over the Orient" (Said, 1978: 3) has enabled him to take a separate stance on discourse from that of Foucault, whose famous dictum "power is everywhere" is, for Said, completely passivist and eliminates "the central dialectic of opposed forces that still underlies modern society" (Said, 1983: 221) and takes no cognizance of "the role of classes, the role of economics, the role of insurgency and rebellion in the society he discusses" (Said, 1983: 244). As Said reveals in After the Last Sky: Palestinian Lives, with photographs by Jean Mohr - one of his most personal books, his idea of discourse was motivated by a relentless sense of loss he incurred through the loss of his motherland to Israel and a commitment to writing-as-action. That one can write within the discursive parameter of the west and create a space for counteractive position was also seriously meditated by him in Beginningsthe book he wrote three years before Orientalism. Here he suggests the possibility- To make explicit what is usually allowed to remain implicit; to state that which, because of professional consensus, is ordinarily not stated or questioned; to begin again rather than to take up writing dutifully at a designated point and in a way ordained by tradition; above all, to write in and as an act of discovery rather than out of respectful obedience to established "truth" - these add up to the production of knowledge, they summarize the method of beginning about which this book turns (Said, 1975: 379).

Thus, Said's growing up into an intellectual had everything of an intriguing career. It had the highest stamp of academic erudition. It was a life lived at the cutting edge of theory on the one hand and on the other, getting actively involved in the politics of the Middle East and engaging more and more with "the world of politics, power, domination, and struggle". This heightened political consciousness that grew out of a dialectic of loss and academic grounding in the highest sense, made him boldly think that his personal history and that of his race cannot be detached from the operations of imperialism and colonialism and that they are not mere abstractions but embodiment of "specific experiences and forms of life" that had "an almost unbearable concreteness" (Alam, 2007). The resolve that was evinced in the Beginnings- a resolve to recast and reread the inherited texts in revisionist ways and write back to the west to re-appropriate the space within the discourse that the west has made its own for long stayed with Said lifelong and provided materials for fashioning an intellectual life whose strength lies in the flexibility regarding the rigidity of ideologies and unflinching daring to challenge the so-called sacrosanctity of intellectual conventions.

This non-coercive model of an intellectual resistance is eminently expostulated in his famous book The world, the text and the critic, where he introduces the idea of secular criticism implying that the critical spirit of an intellectual must not be narrowly obsessed with or 'theologically' bound with any particular doctrine of the world. It must demonstrate a refusal, born out of moral integrity, to be locked into any school, ideology or political party and a determination not to exempt anything from criticism. This critical consciousness which withstands totalizing viewpoint of any particular ideology constitutes his strength and power of resistance against dogmatic tyranny. Said makes it clear that a critic can maintain a respectful relationship to the metaphysical but when it comes to the business of criticism, he must be a committed secularist. Having acknowledged the difficulty for an intellectual to avoid political conversion, while there are many gods around like Communism, Imperialism, Marxism, Nationalism, to name only few of them (Massad, 2004: 7), Said regards the link between criticism and any particular dogma highly damaging to the morale of criticism itself. The history of thought, to say nothing of political movements, is extravagantly illustrative of how the dictum 'solidarity before criticism,' means the end of criticism (Massad, 2004: 8). For Said, secular criticism is directly opposed to such manifestation of dogmatic tyranny like the quasi-religious quietism of complex and abstruse theoretical thought and the ideologically determined positions of intellectualswhom he calls the "priestly caste of acolytes" and "the dogmatic metaphysicians" (Said, 1983: 5). Said doubtfully looks at those critical enterprises that ostensibly operates with lofty ideals of humanism, "of a higher things or ultimate values" (Said, 1994: 89), and only use them as covering acts for mean and selfish culture-specific ends. Said very revealingly comments that the industry of so-called humanistic criticism has come to a point-at which specialization and professionalization allied with cultural dogma, barely sublimated ethnocentrism and nationalism, as well as a surprisingly insistent quasi-religious 
quietism, have transported the professional and academic critic of literature- the most focussed and intensely trained interpreter of texts produced by the culture - into another world altogether. In that relatively untroubled and secluded world there seems to be no contact with the world of events and societies, which modern history, intellectuals and critics have in fact built (Said, 1983: 25).

Obstructed by the parochiality and the narrowness of doctrinaire attachment, an intellectual makes the mistake of not realizing that criticism in itself is not an end, but active, worldly and implicated in the process of representation. In other word, Said posits for the secular criticism the prime role of political engagement whose strength becomes manifest in its resistance of anything that has implication of ideological closure and in it's noncompliance and non-conformity with pre-conceived notions. Thus, the full power of resistance for an intellectual originates in his ability to possess radical skepticism with regard to any dogma or belief and in not taking anything for granted-In its suspicion of totalizing concepts, in its discontent with reified objects, in its impatience with guilds, special interests, imperialized fiefdoms, and orthodox habits of mind, criticism is most itself and, it starts turning into organized dogma (Said, 1983: 29).

A point that is very relevant to be posed here is whether Said's own positions is not in danger here; whether he, in championing the cause of the Palestinians, has not compromised his moral integrity, by being too partisan. Said's answer is disarmingly unambiguous, "Even in the very midst of a battle in which one is unmistakably on one side against another, there should be criticism, because there must be critical consciousness if there are to be issues, problems, values, even lives to be fought for" (Said, 1983: 28). Said's own life as an intellectual is emblematic. Said's defense of Palestinian rights was never bound by his worship at the altar of nationalism, but the opposite: his refusal to accept that Zionism, as a form of nationalism and colonialism, should serve another god for intellectuals. The secular emphasis in criticism resulted in a constant auto critique of his position and enabled him to see that the Jewish history in Europe is as much fundamental as the Christian one, and that they have come from a long tradition of outsiders performing crucial transformation of European Christian society. But that Zionism as a new god is trying to suppress that noble tradition of the Jews and attempting to convert it to a new kind of state worship of Israel is something that draws his criticism (Said, 1983: 14). In a similar vein of secular criticism, Said indicts the role of Palestinian leaders who switched their position, in the wake of
Oslo Treaty, from being stakeholders in the Palestinian liberation movement to be fulltime salaried advisors to Arafat's Palestinian authority. This, for Said, signals the suspension of the critical faculty of Palestinian leaders and a tragic inevitability that befalls those whose political vocation is not based on secular criticism (Said, 1983: 8). His subscription to the ideals of moral transparency, and a commitment to contest power to lay bare inherent inconsistencies within the ruling paradigm sums up the efficacy of secular criticism as an effective tool of resistance.

What gives secular criticism it's strength, an unique quality of resistance is amateurism which is a refusal to be locked into dogma or systematic theory. Theory, as we know, demarcates a ground of specialization; only professionals who have full command over it can make full use of it in their study of texts. The result is always a puzzling one for the common readers. They are unable to intellectually connect with the propositions of theoretical critics and consequently feel occluded in their access to the texts (Bill Ashcroft and Pal Ahluwalia, 2007: 31). Critical theories like Structuralism and PostStructuralism are cases in point. By intensely focusing on textuality or literariness of the text and loading explanation with outré jargons, critics have virtually shut the world of the populace from the rarified world of academia. Textuality, as Said puts it, is the somewhat mystical and disinfected subject matter of literary theory (Bayoumi, Moustafa \& Rubin, 2001: 221). The most hideous aspect of theory-mongering is that, while critics go on about their business of theory unhindered, they are quite indifferent to the fact that there is a world of time where killing and maiming and colonization of the most depraved and brutal kind are being executed by the most acknowledged patrons of humanistic studies of the west.

In having given up the world entirely for the aporias and unthinkable paradoxes of the text, contemporary criticism has retreated from its constituency, the citizens of modern society, who have been left to the hands of the 'free' market forces multinational corporations (Edward Said, 1983: 4).

That is why Said sees theory as existing to support the function of criticism to change things, to provide a perspective on a world which is actually there in the experiences, commitments, and sufferings of all people (Bill Ashcroft and Pal Ahluwalia, 2007: 32). However, Said is quite aware of the irony that for a criticism to be really a criticism, there is always a risk of it solidifying into theory which, in turn, turns out to be an exclusionary and manipulative tool of representation. It is for this reason, theories are favorite with the imperialists; for, 
they are used to divert attention from the burning questions of the time and put construction on reality only in the most abstruse and specialized terms.

A relevant example can be drawn by pointing out the case of Bhabha- another key critic of post colonial studies. Safely ensconced in ivory tower academic position in the west, constantly dangling with textual aporias and the play of signifiers, unscathed by the fire of colonial violence, Bhabha stands out as the perfect example of an intellectual whose moral and critical scrupulousness have been clouded over by professional vanity. It is because of this, he sees Said's attempts to go polemical for the cause of Palestinian liberation as mere 'rage' of a 'passionate oriental' whose rational facilities retreat before emotion (Bhabha, 2004: 19). According to him, the establishment of a Palestinian state will be the violation of a 'hierarchy of historical choices' (Bhabha, 2004: 19) and will directly run counter to the prospect of a 'just and lasting peace' (Bhabha, 2004: 20). Thus, being blithely indifferent to the plight of the Palestinians and to the decades of plunder, rape, expulsion, brutalization heaped upon them by the war-loving Zionists, he speaks of solution for the Palestine-Israel conflict (rather than Israelian colonization) in a tone reminiscent of Said's morally warped professional intellectual who privileges the certainty of staying within the fold of power rather than the uncertainty of challenging it. Bhabha says that the vision of a solution for the Palestinian condition "would be based on a shared awareness that the territorial security of people [sic] is more relevant today than a nationalistic demand for territorial integrity [emphasis in original]' (Bhabha, 2004: 20).

Therefore, Said espouses an approach in which he sees that "criticism is reducible neither to a doctrine nor to a political position and if it is to be in the world and self-aware simultaneously, then it's identity is it's difference from other cultural activities and from systems of thought and method" (Edward Said, 1983: 29). Intellectual amateurism is a moral empowerment of a critic unbound by professional paradigms who play the role of opening debate rather closing it, of challenging and speaking truth to power rather serving and humoring it. He is indeed ready to ask the questions, "why one does it, who benefits from it, how can it reconnect with a personal project and original thoughts" (Edward Said, 1983: 8).

An intellectual as an exile is armed with the plurality of vision and since he shares a simultaneous vision of reality, leading a nomadic decentered, peripheral life, he authors his own meaning in life (John D. Barbour, 2007: 295) and it is this feature of his intellectual make-up that allows him to resist aggression and misrepresentation by ideological machinery of a culture. An intellectual leads an unusual life of being at odd with everything. He is "inconsolable about the past, bitter about the present, and the future" (Bayoumi, Moustafa and Rubin, 2001: 369). The fate of being left at disadvantage with time and place, and his view of himself as a site of identities mostly in conflict with each other (Said, 1999: 5) increase the range and depth of his judgment as he is unbiased and even-minded to all opinions, partisan to none. Not unduly guided by the sympathy for the past left behind nor blindly obliging with the present which is all about bitterness and dissonance, an exile's perception of the world is infinitely critical, contrastive, dispassionately objective and most importantly informed by the dialectics of multiple view-points. Because the exile sees things both in terms of what has been left behind and is actual here and now, there is a double perspective that never sees things in isolation (Bayoumi, Moustafa \& Rubin, 2001: 378; Said, 1994: 44).

The ability to contemplate ideas in aggregate rather than in isolation is the prized ability of an intellectual with exilic consciousness. For, any idea he decides to examine is placed within the range of other competing alternatives, revealing for the investigating mind merits and demerits of a given proposition in proportionate order. This habitual form of comparing and contrasting propositions, arriving at a synthetic conclusion often contrary to the entrenched cultural beliefs and expectations can offer an intellectual insight as to the way culture works through deliberate distortion of reality by producing paradoxes and damaging untruths.

I have felt that most of the alarmist and deeply flawed discussions of Islamic fundamentalism in the west have been intellectually invidious precisely because they have not been compared with Jewish or Christian fundamentalism (Moustafa Bayoumi and Rubin, 2001: 378).

As the above reference to the Islamic fundamentalism implies, the task of unmasking the hypocrisy of the propagandist regime of a dominant culture is an arduous one. A critic who rests on the certainty of the single weight of argument cannot stem the misleading trends of a culture, let alone redress it. What is required for the critic as Said says is the sincerity of their calling, an willingness to possess exilic consciousness that will enable them to transcend the bi-polar world of judgment forever cast against "an approved enemy" (Moustafa Bayoumi and Rubin, 2001: 378) and reach a point where he can declare with honest courage and determination what is what in a culture.

The power to demystify is the great tool of resistance for an ideal Saidian intellectual as exile who considers life in transition and fully contingent. 
In this regard, Said is directly indebted to Giambattista Vico who was his 'hero' and whose teaching was "that the proper way to understand social reality is to understand it as a process generated from its point of origin" (Moustafa Bayoumi and Andrew Rubin, 2001: 379). When things are considered contingent, transitory, part of process, what follows inevitably is the realization that nothing in this world is inevitable, permanent. Even time-honoured concepts of god, king and state are not absolute, inviolable as they seem, since they can be traced to humble 'beginnings'. The upshot of this is the skeptical attitude in intellectual who, undaunted by the august personality or magnificence of institution surveys, examines and probes identities into constitutive elements. Emboldened by the radical skepticism like that of Adorno who was known for "hating all systems, whether on our side or theirs, with equal distaste" (Moustafa and Rubin, 2001: $375)$, an intellectual is able to demystify the religicomythical sanctity of ideologies, orthodoxies or even tradition and shows to the people what they truly are, that they are bound-up with origins that may deserve attention but not veneration. It is not the provisional wholeness of satisfaction nor the comfort of living with the status quo that the Saidian intellectual is after, nor he fetishises the life of an exile as that of a glamorous reactionary (Ayyash, Muhannad, 2010: 114) but plays the role of the demystifier of history the notion that history is made a certain way and could thus be made otherwise (Ayyash, Muhannad, 2010: 114).

However, this power of an intellectual is consequent upon how he takes the meaning of being exiled-literally or metaphorically. The tale of Said's personal life which betrays a pattern of dual relationship to in- placeness and out of placeness are interestingly linked to Israeli and Palestinian narratives of nationalism (Alon, Confino, 2000: 194). And the dynamic of this dual relationship which both connects him to the world and repels from it continuously fractures his self and gives to his existence a metaphorical state of exiledom. For a metaphorically exiled intellectual, life is a place of endless trials and tribulations, of constant pangs of exclusion, of uninterrupted vigilance against uncritical identification with any dogma.

The pattern that sets the course for the intellectual as outsider is best exemplified by the conditions of exile, the state of never being fully adjusted, always feeling outside the chatty familiar world inhabited by natives, so to speak, tending to avoid or even dislike the trappings of accommodation and national well-being (Said, 1994: 39; Moustafa Bayoumi and Rubin, 2001: 378).
For a critic to embrace any dogma is to reach a point of passivity, to sacrifice the voice of conscience whose energy lies principally in its separation from all systems and in making scrupulous judgment on everything. Even if a side is provisionally taken for the sake of argument that, in further turning, must be subject to more rigorous scrutiny and the process will go on ad infinitum. This judgment, for Said, can effectively belong to an intellectual as exile. His grounded sense of belonging to a home disrupted by the loss of it constitutes an special moment of life that gives rise to experiences of not just pathos but also of a gain in the manifestation of aesthetic development, sharpening of critical vision, vociferation of a critically informed voice - a power that Said nuancedly terms "the executive power of exile" that enabled the great German intellectual, Auerbach in Istanbul to write Mimesis. The benefit of living in such "a condition of marginality" (Moustafa Bayoumi and Rubin, 2001: 380) is clear: freed from the task of conforming to all configurations of political and cultural systems, the undomesticated self of the exilic intellectual responds to the audacity of posing awkward and puzzling questions, resisting ideological closures, totalization, discrimination, aporias, showing ever-renewed commitment "to moving on, not standing still" (Moustafa Bayoumi and Rubin, 2001: 381).

It is important for a secular critic to consider a text as the product of the world rather than an abstract de-historicized artifact and thereby, bring to surface the real scenario of political and cultural leverage that a text can wield upon human society. In considering the ways a text stands in relation to the world, Said comes up with two distinctive termsfiliation and affiliation. While filiative relationship places a text within a tradition on the basis of chronology and homogeneity with other texts in the canon similar to the model of father-son relationship, affiliative relationship regards diverse worldly circumstances, social and cultural determinants by which a text comes into being. Unlike filiative relationship which places a text on direct correspondence with other objects in tradition, affiliative one investigates ways of how cultural conflicts between nation, contestations of power and imperialistic authorial ambition inscribe within a text nuances of power-structures, which not only prevents a facile estimation of it as simple aesthetic product but look at it as a product of the world in which, the interest of the author, the culture he defends, the values he embodies have the decisive say. Once it is understood by the secular critic that a text implies "status of the author, historical moment, conditions of publications, diffusion and reception, values drawn upon, values and ideas assumed, a framework of 
consensually held tacit assumption, presumed background and so on" (Said, 1983: 174-175), the whole ideological mapping of the text, its cultural texture becomes available for critics scrutiny, enabling him to go trans-cultural, most importantly enabling him to explore cultures for their comparative excellencies and deficiencies from an objectively critical distance. This frees a critic from being narrowly protective about any particular culture and urges him to consolidate his position by taking a global stand on any issue which affects humanity irrespective of their geo-political identity. To consider the worldliness is, therefore, to give to criticism an edge of nobility, to do the task that a critic should fearlessly do-"to make visible, to give materiality back to, the strands holding the text to society, author and culture" (Said, 1983: 175).

However, the worldliness of secular criticism works successfully when critics apply the method of contrapuntal reading on major literary texts of Europe. The method is in short is a form of reading back from the perspective of the colonized to the grand, seemingly, uncontestable history of the imperial west. One major point in Culture and Imperialism is that as an art form, novel works as an aesthetic accompaniment to imperial expansion (Bill Ashcroft and Pal Ahluwalia, 2007: 93). This is facilitated by an observed normative value known as "structure of attitude and reference" (Said, 1993: 91) that each novel maintains with other novels in sustaining a concealed but dense inter-relationship between culture and imperial enterprise. Indebted to Glenn Gould who exemplified contrapuntal performance in designating a polyphonic variety in melody, Said admires this particular kind because it allows maximum advantage and freedom to all the competing themes in melody. Using this concept of polyphony, Said attempts to read major texts in Europe excavating for imperial message otherwise hidden, codified, barely visible in their margins and smoothed over by a picture of trouble-free, organic, rational life of the imperial west. By making visible the submerged history of the colonized, contrapuntal reading, in reality, illuminates dense affiliative network of imperialistic and anti-imperialistic perspectives of a text, revealing in the process its worldliness, its "overlapping and interconnected experiences" (Said, 1993: 36) of people and nations. Thus in Mansfield Park an apparently innocent description of sugar plantation can be contrapuntally understood to have carried authors' pro-colonial investment of keeping order back in England. It is important for us to remember what Said said while referring to Raymond Williams' work The Country and The City that "for every poem or novel in the canon there is a social fact being requisitioned for the page, a human life engaged, a class suppressed or elevated ....." (Moustafa Bayoumi \& Rubin, 2001: 238).

To make the invisible visible, to give the voiceless, faceless a chance to be heard and read in the metropolis is the task of contrapuntal reading and it is done by avoiding that rhetorics of blame too familiar with many critics in the west and east. It is not meant to disparage any particular viewpoint at the cost of other (Said, 1993: 19). It is in this spirit Said called for equality and democracy in a projected binational Israel/Palestine state where the Palestinian and the Jew can live with equal rights, free from the racist laws and privileges that continue to reign in Israel, and free from the violence of the Israeli military offensive and terrorist counter attack. Said belief in contrapuntal reading as an effective tool of unveiling inconsistencies in dominant discourses allowed him to stand against the inherent flaws that one can witness, as Joseph Massad informs in the following comments, in the Orientalist discourse.

Western epistemological discourses function to shape the orient as one way discourse 'The Orientalist can imitate the Orient without the opposite being true. What he says about the Orient is therefore to be understood as description obtained in a one-way exchange: as they spoke and behaved, he observed and wrote down. His power was to have existed amongst them as a native speaker, as it were, and also as a secret writer. And what he wrote was intended as useful knowledge, not for them, but for Europe and its various disseminative institutions' (Massad, 2004: 10; Said, 1978: 160).

All of Said's theoretical models of resistance point to the all-important one- voyage in, a term which implies a literary cum cultural mode of resistance. Said makes a scrupulous distinction between mere colonial oppositionality and colonial resistance. Colonial opposition often runs the risk of taking the proposition of armed battle which quickly degenerates into genocide, pogrom and more dangerously separatist nationalist consciousness such as negritude which divides the world into paranoid frontiers-us and them. For a secular critic like Said, the idea of resistance is linked with universal liberation and emancipation. Resistance does not simply denote conflict but redefinition of cultural territory of dominant discourses of the west by writing back or what Said will say 'voyaging in'.

This involves participating the imperial discourses, appropriating the tools of imperial scholarship and transforming them with the experience of the colonized which act as 'scars of humiliating wounds, as instigation for different practices, as potentially revised visions of the past tending towards a post-colonial future' (Said, 1993: 256; Bill Ashcroft and Pal Ahluwalia, 2007: 108). As the study of contrapuntality suggests that 
any literary text on either side of the colonial divide has a dense fabric of inter-relationship between the colonizer and the colonized, post-colonial writers who want to 'voyage in' (Said, 1993: 262) can tap the avenue of discursive communication by reformulating, re-reading, re-writing the canonical text of the west from their perspective, with the advantage that they cannot be denied outright, since they follow the epistemic registers that the - west itself has introduced. Hence the task of writing-back confers upon a canonical text multiplicity of perspectives, considering it as a hybrid work and confirming what Said said ".... that Texts are not finished objects" (Said, 1993: 312) and it is important to read not just what it is but what it can be made into.

This non-coercive counter-narrative is congruent with Said's Fanonian ontology of identity. He is one who does not hesitate to denounce colonialism but he agrees with Fanon that identity cannot be selfreferential; it is the historical dualism of self and other by which agency is created over political and intellectual contest of power. Like fanon he is aware of historical pitfalls of nationalist consciousness and prescribes transcendence of "warring of essences" (Said, 1993: 277) to a socialist consciousness. Said is ready to acknowledge that the great imperial experience of the past two hundred years is global and universal; it has implicated every corner of the globe, the colonizer and colonized together (Said, 1993: 313; Bill Ashcroft and Pal Ahluwalia, 2007: 114). This honesty and integrity is characteristic of the man-Said himself. In view of this fact that the fate of the colonizer and colonized is bound together by a historical logic and that even decolonization cannot free them from psychological antipathy, Said believes that intellectual vocation for resistance against social and political injustice and anomalies should be based on "non-adversarial community of awareness" (Said, 1993: 330) tending towards transformation and co-existence in a world where internal dialogue and self-enhancing self-criticism is always open between cultures.

In a carefully chosen path in which he refuses to sacrifice his moral and intellectual integrity to political partisanship and resists the temptation for selfaggrandizement by being a card-carrying intellectual for a dominant system, Said practices this self-criticism in the strictest sense and plays the role of a whistle-blower, on all collusive and conspiratorial machineries of system. He then exemplifies that, with due respect for people and their intertwined histories, without having the cheap satisfaction of participating the blaming game, an intellectual can intervene against the excess of a totalitarian system in a discerningly strategic manner, very essential in a world where the walls of ideological hostilities are closing around us fast.

\section{Conclusion}

Said's conception of resistance is a result of conscious intellectual program, not some half-baked fantasized scheme. With the experience of living in the most powerful imperial culture ever, Said, trained in Gramscian hegemony and Foucaultian discourse, could say very confidently that, cultural representation is in fact misrepresentation and that, the representation is a task that necessarily reflects the ideological viewpoint of the dominant culture. This epistemological power to represent or narrate 'the other' as in art and literature is a vintage opportunity by which a dominant culture enjoys a sway over the weaker one and places it in a disadvantageous position within the discourse. The end result of such hegemonic misappropriation is inevitably disastrous one- division of human reality, systematic production and reproduction of institutionalized knowledge like Orientalism that intrinsically deepens and aggravates such division in academically approved but shrewd ways. It is here that an intellectual, Said believes, can step in and resist the retrograde tendency in a culture. What facilitates this task of his, is his ability to practise secular criticism. Without being sucked into the ideological maelstrom, picking carefully his way through the rivaling doctrines and passing comparative value-judgments on them, an intellectual can be a formidable force to reckon with. And his connection to people and to the world at large is secured by his prowess to produce jargon-free statements and to deal with disciplines as an amateur rather than as an expert.

However, it is highly imperative for an intellectual to have, Said stresses, exilic consciousness, a state of level-headed detachment from emotional catchments that imparts to his intellectual posture certain candor, purpose and strong-willed determination as he goes on to consider every discourse in a new light, challenge the seemingly impeccable, contest the incontestable. In other word, he must not content himself with the sanctified face of the tradition but ask precisely those questions that unsettle- what makes tradition in the first place. Finally, an intellectual is a person qualified enough to comprehend the totalitarian language of discourse and he can, if he wants, resist it by producing counter-discourse. In outlining the clear course of intellectual resistance, Said has virtually ensured the immortality of himself as the most powerful cultural critic in the broad spectrum of postcolonial studies. For, resistance, the by-word in this department, is effectively formulated by him and can be universally followed. 


\section{References}

Alam, Fakrul (2007) Edward Said and the Counter Discourse of Postcolonial in ed. Book Imperial Entanglements and Literature in English, The University Press Limited, Dhaka, pp. 235-253.

Ashcroft, Bill and Pal Ahluwalia (2007). Edward Said. Routledge, USA, Canada.

Ayyash, Mark Muhannad (2010) Edward Said Writing in Exile, Comparative Studies of South Asia, Africa and the Middle East, 30(1), 107-118, Duke University Press.

Barbour, John D. (2007) Edward Said and the Space of Exile, Literature \& Theology, 21(3),293-301, Oxford University Press.

Bayoumi, Moustafa and Andrew Rubin. (2001). The Edward Said Reader, Granta Books, London.

Bhabha, Homi K. (2004) Untimely Ends, Artforum International, Vol. 42, No. 6 (February 2004).

Confino, Alon (2000) Remembering Talbiyah: On Edward Said's Out of Place, Israel Studies, 5(2), 182-198, Indiana University Press, Fall 2000.

Deane, Seamus (2001) Under Eastern and Western Eyes, boundary 2, 28(1), Spring 2001, 1-18, Duke University Press
Massad, Joseph ( 2004) The Intellectual Life of Edward Said, Journal of Palestine Studies, 33(3),7-22, University of California Press.

Said, Edward (1975). Beginnings: Intention and Method, New York: Basic Books.

Said, Edward (1978). Orientalism, New York: Pantheon Books.

Said, Edward (1983). The World, the Text and the Critic, Cambridge, MA: Harvard University Press.

Said, Edward (1986). Intellectuals in the Post-Colonial World, Salmagundi, 70(1), 44-80.

Said, Edward (1986). After the Last Sky: Palestinian Lives, with photographs by Jean Mohr, New York: Pantheon Books.

Said, Edward (1993). Culture and Imperialism, New York: Alfred A Knofp.

Said, Edward (1994). Represents of the Intellectual: the 1993 Reith Lectures. New York: Pantheon Books.

Said, Edward (1999). Out of Place: A Memoir, New York.

Yacoubi, Youssef (2005). Edward Said, Eqbal Ahmad, and Salman Rushdie: Resisting the Ambivalence of Postcolonial Theory, Alif: Journal of Comparative Poetics, No. 25, Edward Said and Critical Decolonization, pp. 193-218, Published by: Department of English and Comparative Literature, American University in Cairo and American University in Cairo Press. 